\title{
ASPECTS OF SOCIAL SECURITY IN THE CONTEXT OF DEMOCRACY DEVELOPMENT OF THE WESTERN BALKANS
}

\author{
Milica Mladenovic, MSc \\ S4 GLOSEC Globalna bezbednost doo, \\ E-mail: milica.mladenovic@glosec.rs \\ Zoran Lapcevic, MSc \\ JKP Obrenovac, \\ E-mail: jkplapcevic@magnetplus.net \\ Nenad Komazec, MSc \\ Military academy, \\ e-mail: nkomazec@gmail.com
}

\begin{abstract}
Western Balkan, given its multiethnicity, represent a constant challenge for democratic change in society. Security of society represents one of the indicators and factors of democracy. Safe society is a democratic society. Any form of deviations from the democratic achievements of factors finds roots in the security of society. In the modern societies, security has a safety function of the preferred, and in particular in the society such as are specific for the Western Balkan. Society in the Western Balkans are a striking example of "risk society". Safety achievements of these communities, in the future will have a major impact on the development of democracy. Risk society is basically a challenge to the development of democracy in the societies of the Western Balkans. Managing the security risk in the years to come, there is a possibility of preventing many negative events. Creating prerequisites, event management that can be triggers of negative effects of social events.
\end{abstract}


Key words: social safety, western Balkan, democracy.

\section{INTRODUCTION}

The exercise of basic needs for a man from the beggining has been representing a top priority. Success in that achieving to a number of different factors, which are in different ways and with different consequences prevented the man with the intention of realizing their needs. The result of the operation of different forces is always the same, which means that man suffered. Starting from the natural disasters, which had not understood, by other people who wanted to take over his prey, the environment had becoming more and more dangerous. Breach certain values that the man felt he had to protect them. The value motives are simply justified by the need to protect fundamental values. With this approach, man is defined by his environment and suggested what are his intentions. From defined values man had defined his interests, respectively the way in which he sightings relative to environment. The circumstances in which a man works become more complicated and from an aspect of the number of factors and from the aspect of increasing the number of hazards. Similarity of defined interests among individuals caused the recognition of possibilities of association in order to achieve common goals. Joining the different groups brought certain advantages in the field of joint action against certain dangers, but also brought new conditions of living and the realization of life needs. In social groups there had been developing new relationships, which are run by then by unknown forces, which represented new threats. So, man had no particular problems, those had risen on the social level, and with it has increased the level of complexity of relationships between people. Simply, a need imposed to a man to protect his value, in order to achieve its purposes. To realize this, he had to create an environment in which there is no danger, and safe environment. On creation of such an environment influenced by many factors and forces in nature and community groups.

The effects of various hazards, throughout history, not only had a simple explanation for the simple consequences, although the writers of history have shown. The consequences were local but also much broader character. For all that he could not explain, man was attributed to "higher powers". Informations about the accidents could not be far away to hear, because there was no way to communicate. Today, through the 


\section{Seccurity}

Internet in a few seconds the information arrives anywhere in the world. It is sometimes sufficient condition to protect people from the impending danger. Regardless of the technological possibilities, today those with power try to sell only information that are important to them, regardless of how much it will have secondary effects on people, property and the environment. Precisely, the destructive capacity of the danger, determine its importance to society, and not the opinion and attitude of those in charge.

The consequences, regardless of whether they are designed or real, implied the suffering for the people. Suffering exerts its effect on society as much as on an individual. However, society is in a position to always implement specific mechanisms for their protection, while an individual does not have that privilege, because in many cases depends on the society. Precisely, because of the necessity of agreement holders, about the attitude that you need to act in a certain situation, individuals are deprived of help, at least for a while. Dangers that have long-term consequences, affecting a part or the whole society, the disruption of the normal functioning of society, cause a special state of society, in other words the crisis. In emergency situations, security is gaining in importance. Security becomes the priority activity. Society becomes more susceptible to the effects of various hazards and wants to protect from them.

\section{ORIGIN AND SOCIAL PRESUPPOSITIONS OF SAFETY}

Cood and evil have always had the attributes of interesting questions for the man in terms of the impact on its safe life and work. These issues, and their impact on humans, represented a kind of philosophical consciousness, which was aimed at determining the cause of evil.

The first data on reflections on the causes of harm to humans date back to ancient times. Culture such as Chinese, Indian, Phoenician develop original ethical considerations about the causes of evil. Basically, the drivers of the evil events found in the man or his egoism. The point is that a person does not submit their personal goals to a society or group. Driver of human behavior characterized by negative event is avoiding pain and create prosperity. In doing all to live in prosperity a man does not choose the means, which causing causing negative events. Such considerations went even so far that good and evil was set as a dialectical unity, the unity of opposites. 


\section{Security}

However, there were also more advanced thinkings, focused on the structural conditionality collective social evil forms. Rulers and the administrations of the then country kept the people in constant tension, making the bad things that had people ready for war and the realization of their goals. Such methods had been awakening consciousness in an individual or a group, which has led to the organizations of various protection from such behavior. (Kekovic, 2009)

The development of society brought new ideas on security considerations. In ancient times, there is the question of justice. Considering that statesmen must find ways to govern justly, without tyranny with the aspiration to rule, that will allow avoiding negative events. The idea of preventive combating evil, creates a basis to think about the interconnection of people to achieve security.

Medieval thought, with the Roman Empire at the head, promotes the ideas of universality, based on linking the spiritual and secular authorities, and therefore the termination of the reason for the existence of discontent among the people. This idea did not survive, but is separated spiritual and secular authority, and the idea of universality led to the national interests of different countries.

In the new century is developed the universalistic idea of establishing a new and just international order, where ethics were above the power and oppression, and the power of arms replaced the power of public opinion.

Today the idea of universality is a platform for the theory of globalization.

\subsection{Danger as aprerequisite for security}

What is dangerous and how to behave in the formation of risks are the questions which man seeks for a response from its inception. Human history is rich in events, with dramatic and destructive effects, due to which a man suffered by negative consequences. Situations and events that jeopardized the survival of man occurred in different forms, with different intensity and characteristics. In such a situation, in their evolution and socio-cultural development, man has tried in various ways, in his environment, to combat dangers by restricting and hampering the realization of their needs. Various events have acted in different ways, but one thing was in common, a man suffered pain and was obstructed to meet all his needs. The troubles that had afflicted man were unpredictable, multi-dimensional, without time and space limitations, and the effects were devastating. There were various attempts for events 
with negative effects to prevent or at least to reduce, resulted in various measures undertaken by the people in order to achieve a certain degree of protection. Although scientific achievements are at a very high level of development, man is still threaten by the same or similar hazards, whose effects are larger in terms of capacity increase due to the danger of technological development and the increasing number of residents per business unit. Events that are potentially hazardous to a man and the surrounding area, with the epithet destructiveness can be classified into:

- events due to normal operation (fire, floods, volcanic eruptions, disease)

- events that cause human error (fires, accidents, chemical accidents) and

- events technical and technological origin (nuclear and radiation accidents, fires and explosions, spills of hazardous substances).

Therefore, all of the above events have the capacity to inflict man and his environment some damage and therefore to pose a risk to humans. Analyzing the causes of the events listed can conclude that a man is the central figure of causality by many dangers.

It remains an open question how to behave when certain risks incurre. In the modern world, this question becomes topical because of the destructive effects of increasing the capacity of individual risk. The mere fact that the consequences of modern danger of increased manifold inevitably implies the development of an appropriate protection measures. Increased destructive capacity of modern threats, in addition to consequences for people, property and the environment, causes and consequences of long-term and multidimensional character, which social groups bring into a special state, when there must make decisions about care in terms of lack of time, the deficit of information and resources. The effectiveness of protective measures requires the answers to several problems: (Geneva: UN International strategy for Disaster reduction)

-the earliest detection of the causes of hazards;

-the possibility of preventive planning and operation during negative events;

-the existence of the current power response;

-way of engaging all the capacity of society;

-type and mode of application of the measures upon termination of danger.

Mentioned facts imply the human need for existence in an environment where there is no risk or are so weak that they do not restrict the exercise of basic needs. Environment without the presence of danger is called a safe environment. The safe 
state of the environment includes the two most important areas of social existence: the area of physical existence and material well-being.

In addition to the substantive definition of danger it is necessary to take into account also the elements that are in touch of the possibility of protection when it comes to the realization of danger. The resulting need to protect society and its inability, and / or the ability to provide a certain level of protection, shows the security conditions at the given time (Figure 1). The relation between two named conditions is disproportional which indicates the level of security. Namely, if the needs are big and possibilities are small, the security is low and vice versa if the needs are small and possibilities are big, safety is at a solid level. (Byme and Baden, 1995)

Finally, the basic characteristics of the danger, which is also the central figure of the social interests in the struggle for a safe environment, are the consequences. The consequences are the effect of causing a danger to society and its values. Negative consequences are primarily interesting for a society. Total deliberation and action of society is directed to finding measures with which can effectively operate in a risk to rebate or reduce consequences.

\subsection{Endangering as a social phenomenon}

Various forms of dangers with the portfolio of consequences, besides other factors influencing by human existence, were directed by individuals to association. People quickly realized the benefits and benefits of grouping and association, in terms of providing easier protection. Thus, danger and endangerment was not the thing of an individual, but of a group or a society. The question that arises is why the threat was premature to society. Since the threat represents a series of related phenomena, processes, interactions, and their source of origin, it can be concluded that it has an impact on all flows and processes in society and in all social groups. So, endangering represents a social phenomenon in the form of a particular event or behavior of lasting character which in social life causes a negative consequence. (Dragisic, 2007)

For a fuller consideration of the impact of the danger, the threats, the society, it is necessary to determine the nature, character and content endangering.

The central place, in the process endangering society, takes the value of the company that is trying to maintain. The values of society are the very essence of human 


\section{Seccurity}

struggle for a safe environment, and can be in terms of social life related to moral and social achievements, culture, property, etc.

Social character of threats is represented by the fact that the society is deteriorated due to different threats, for example: of other groups, natural disasters, its own technical and technological progress, and so on. Diversity compromising implies also a diversity of measures which must be undertaken because of protection. An individual does not have the capacity to undertake more global rate, but society has. The development of society has caused the need for a systematic approach to the development of measures to protect the values of society and mechanisms grouped in various specialized areas. (Kekovic, 2009)

Important role in defining threats to society occupies the cause of endangerment. The fact is that the endangerment occurs when conditions are necessary and sufficient which produced the danger or represent a source of hazard. From the above it can be concluded that all processes and events in society and its environment are not by themselves a danger that they do not have primary compromising character. This feature, talk that a variety of causes determines the character of compromising, so, it occurs like a natural, social or psychic phenomena. (Kovacevic, 1996) Endangering caused by natural phenomena refers to natural and other disasters, and social phenomena on different types of wars, terrorist acts and the like. Mental element in the phenomena of compromising consists in the fact that they mainly express consciously of individuals or social groups, in order to achieve a specific goal. Respectively, consciousness of a specific goal, in certain circumstances, can be a cause of contaminating.

A special place in the interpretation of the concept of threat in social phenomena takes up the question of threat. Subject compromising is closely linked with the values of society. The content of the values of society, as a subject of compromising, is determined by the goals and tasks of the society. Depending on the social goals, in defining the scope of protection there are included Institutional forms of society, such as political system, territory, human lives, and the like. In this way, at the same time there are also concretization phenomena of endangering society, because there is no threat to you on the subject of a social value. (Kekovic, 2009).

Development of social relations has implicated also a development of the way of thinking about possibilities of threatening in sociality. Those reflections brought to a 
conclusion that is not enough only to protect basic value of society, human life. It is created a need for protection of material goods, social institutions, environment.

Modern society, due to the high degree of technological progress, has reached a high level of development measures and the system of protection of social values from compromising. The phenomena that threaten society today is not uncommon, but their contents are known to some extent. In the majority of the phenomena threatening character as mystery remains during implementation.

\subsection{Social safety as a presupposition of democracy}

Security concept is designed for a long time relative to military threats. However, the progress and development of technical and technological possibilities of the modern world, in addition to improving military threats have reached a level at which they increased and non-military threats to security. So that, security is no longer representing a primary understanding the nature of the threat, but also understanding in which way is shaped and manifested a security threat. This approach arose from the need to respond to the increasing number of threats in the sphere of security. Due to the great political and economic changes in the late $20^{\text {th }}$ century, a growing number of non-military threats to security, the security focus shifted from state-centric focus on the individual and society. (Hajnsmas, 2006) There was a holistic approach in understanding and reflection of the concept of security. It is about the state of the vital interests of the individual, society and state from internal and external threats and risks of different nature and character, both globally and locally.

The variety of social, political and economic factors in the new social context, cast a shadow on the primary character of social security, due to the inevitability of appearance of its technical aspects. This fact indicates a more dimensional perception of security, arising precisely from the need to interpret that security is not only assuming fulfillment of basic function and survival and functioning of an individual or group.

New approaches to observing the security phenomena indicate the existence of a need for security behavior within develop and maintain security attitudes of individuals and groups, with the aim of raising awareness of their necessity.

The long-term reference object of security - the country is slowly moving from the central framework of security and his place is taken by an individual. Changing 


\section{Seccurity}

considerations referent object of security, there is a change of meaning of many terms related to safety. Among these terms there is a culture of security, which appears in a new light in consideration of security, and points to the behavior in the context of security. However, this phrase had its foundation in the past, but now receives its full meaning by placing the individual at the pedestal of the idea of security. (Nye, 2003) The unstoppable and permanent transformation process safety is reflected in the change in perceptions of the concept of security. Thus, the state is no longer the main subject of interest to study the science of safety. The primary place of the country took the transnational and international organizations, nations, national minorities, professional and marginalized groups as the most numerous safety factors - individuals. (Nye, 2003)

As the number of reference objects of security increases, also and interest in safety culture increases. Also, by extending the list of reference objects of security, sense of the term safety culture is becoming more complex. It is no longer the main issue of safety culture how to educate and bring up a nation in the area of security, but how to do this with each individual separately. Thus, in terms of security, with education and upbringing there should be the beginning from the " bottom ", where the goal is individuals, but also the " top ", where the goal is society at the local level, regional and international levels.

In the way of attempts and intention of defining the content of the concept of security, there were created the phrase challenges, risks and threats. Justification occurrence of those phrases is rooted in the complexity and multidimensionality of security as a phenomenon, but also the state and society as a complex mechanism.

Efforts to be registered and meet all the causes that lead to the appearance of danger to the values of society, led to the creation of security challenges. With good reason, because the causes of hazards are associated with the emergence of threats to the same values which are located in the economic, environmental, politic and other phenomena. The correlation between the challenges and threats to the values of society there exist, but the challenges are more general term, which according to the above applies to all phenomena, regardless of whether they have a threatening character or not. The perception of phenomena that pose challenges to the moment that determines whether a phenomenon to get the title of compromising, depending on factors, causes and possible effects. Challenge as an occurrence represents a value-term, up to the point of establishing a correlation between the occurrence of event, which are subject 


\section{Seccurity}

to security considerations, the possible adverse context. Value-neutrality of this concept is contained also in ignorance of its probability events.

Since the security challenges directly depend on the type and characteristics of the phenomenon that define them and exhibit, it may be concluded that the characteristics and mode of operation of the original phenomena determines the character and intensity of the challenges of the security of society. On the forms and ways of endangering society affect two groups of factors: the first are those who generate them, enable and develop the other are those who prevent them, limit and prevent. (Kekovic, 2009) The fact is that these groups of factors on the phenomena act divergent, or indicate that the phenomenon can have positive and negative character. Positive character is reflected in the absence of danger, and negative in its presence.

Such status, with elements of uncertainty, talks about the possibility that the outcome of the event is positive or negative in given circumstances. Such a possibility is based on uncertainty, to which we can achieve a certain effect, called a risk. From the above, it is evident that the risk has elements that indicate the course of events aimed at maintaining or increasing safety but also to a lack of security and the existence of compromising. Thus, the risk cannot be used in the celebration of the negative context of security phenomena. In this context, the risk can be defined as a possibility, a certain degree of probability of occurrence of an event with adverse consequences. If the risk has unacceptable character for the projected level of security in relation to the observed phenomena, it represents a characteristic phenomenon which acquired the status of threats to the values of society. So, the threat is the same phenomenon that was a challenge, a value-neutral phenomenon, which now has the capacity and the likelihood to exert negative effects on the values of society, characterized by an unacceptable risk. The threat may be broadly understood as a kind of pressure from a position of strength, which the opposite side is wanted to be intimidated and exhausted, in order to compel certain concessions. (Military lexicon, 1981) The threat is characterized by well-known probability of occurrence. The measure of probability of realization depends on the threat identified and of a determined risk, the present and the defined through an analysis of the legality, and the events and the development of certain phenomena.

The relation between the challenges, risks and threats, has its foundation in the triangle which consists of the conditions which are specific contrary, the intention of the determined risk and the force in order to carry a threat. 
The special status, in modern science security, is consideration of the relationship of security and freedom. Specifically, the question is how much freedom a man is willing to give up for security and vice versa. (Kekovic, 2009) Great controversy in the development of future relations in the modern world represents a harmonization of the relationship between security and freedom. Precisely, the freedom of man as the supreme value is the ideal on which is based today's neoliberal conception of development of world society and which has served for the degradation of the communist system, which did not leave room for a maximum emancipation of human freedom. If freedom represents the absence of limitations and life without the ban, it is necessary to identify all forms of freedom that are dangerous and determine ways to protect themselves from them. That is, we come to the crucial moment, as well as how to create enough security to enjoy maximum freedom. The question is whether a democracy and freedom?

\section{SOCIAL SECURITY THREAT IN THE WESTERN BALKAN}

The Western Balkan is a recent term, and in the security and political terms means space of Albania and the former republics of Yugoslavia, without Slovenia. The geopolitical significance of the Western Balkan, in fact, reflects the essential characteristics of the Balkans as well as the wider region and the "Balkanization" as a process of disintegrating and conflict among the people. The geopolitical situation of the Western Balkan distinguished locations in strategically important area Rimland the coastal zone between the Mediterranean sea and Hartland - Eurasian continental core. From this position, arise two basic determinants of the Western Balkan: transition and heterogeneity. Both determinants are often the cause of the bloodiest conflicts of the Balkan nations. (Sretenovic, 2010)

\subsection{Characteristics of social security in the Western Balkan}

Understanding the social security in the Western Balkans is not possible without analysis and understanding of conflicts in communities. Conflicts arise between communities for the exercise of the fundamental basic needs, food, shelter, energy, territory, etc. This fact speaks about the existence and security of a formal association 


\section{Seccurity}

in state creation. Inevitably there were various reasons that one community has more land or livestock, which was reason enough for the development of inequality and the emergence of conflict. Clashes were directed towards violent seizure of material things but also the territory, followed by a large number of casualties and material destruction. Stronger communities have obeyed the weaker members and turned them into their slaves. (Simic, 2002) The new reality of a combination of generation according to calamitous events, conscious and unconscious gesture and events give rise to the creation of social relations. In order to conclude that social relations created in the function of satisfying social needs. Social relations, now as a process are in the form of connecting people in which they enter into definite relations. Social relations are divided into malleable and situational, by determining whether caused by the will of a human or independent thereof, by the nature of the dynamics of the process and the cooperation of the conflict, according to its effects on the process of creation and destruction. (Fiamengo, 1974) From the above it can be concluded that social processes are multidimensional and complex processes. From such processes occur social formations also, with the same character. Since there is a necessary and unavoidable needs that enabling social environment without risk to the values of society, it can be concluded that the safety is a complex social phenomenon. And based on this fact we are developing various security systems as a social creation.

The Western Balkan has passed several times through various integration processes and disintegration. In addition to all these major processes, today's schedule of state creations, is created by conflicts. This is why they can indicate damage or interference to the consolidation of democracy in the Western Balkan may be in the next period to cause further conflicts. This damage can occur only with the kindling of the conflict by various political currents in the maelstrom of external interests. The sight will also be a state of political normality (law and order). Completely new question arises if enrolled lineup, the scenario according to which a country falls into an even deeper crisis, or if any of them directly close the dissolution or disappearance. (Hadzic, 2009)

Security as a social phenomenon and the process was created as a response to the problem of meeting the needs of society for a safe environment to live and work. Effects and directions of social processes generate phenomena of creation (progress) and the occurrence of destruction (compromising). Constant fluctuations by social relations lead to the formation of both phenomena. Security as a phenomenon, the 


\section{Securiagues}

administration had a duty to find ways to define social space to restrict or prevent the occurrence of endangering the progress of society.

\subsection{The Company risk-based social security in the Western Balkan}

The last two centuries represent the time of intensive advancement and progress in technical and technological, economic and demographic terms. Such progress has many theoreticians and practitioners put in doubt and questions whether such progress s positive, what are the effects of it and whether it makes sense. The reason for that is realistic and based on the observation of the fact that along with the progress of developing and increasing the dangers that threaten the destruction of man and the planet. The world is sharply divided in a subject (human) and the object (nature, society, technique). Philosophical postulates of the unity of man and nature are forgotten and lost their meaning. The man reached for the complete mastery and heartless exploitation of nature, the environment and other man, with the intention to do so and with the universe. In addition to other powers, and science itself is partly used as a means of instrumentalization of mind. Special contribution was given ideology excessive spending that has intensified and indifference towards nature and towards other people. Therefore, it is only certain that the future is 'more uncertain than ever before. (Beck, 1992)

This way of development and progress of human society in general and the Balkan region shows that it is increasingly vulnerable. The vulnerability is reflected in the different examples: a growing number of devastating natural phenomena, poverty, the gap between rich and poor, the collapse of national economies, and so on. Thus, social activity contributes to the main driver for the emergence and development of the growing danger to our own existence. Big question mark is standing over the current ways and directions of development of societies in the Balkan, the whole social function of science and technology and enforceable forms of culture.

The highlight progress and development is not only reflected in the technical and technological development, which is the initiator of many other processes, but also in the field of consciousness and culture, then the economy and security. Certain advanced society, the neoliberal orientation, contributed to the creation of a special and unique idea of uniting the world into a global village, and the idea of globalization. Globalization as a process is one of the products of technological progress. Founded on 
the capitalist economy, global awareness, global social system and military order of globalization tend to delete national characteristics and their subordination to global interests. (Stojanovic, 2009) Global interests project the interests of the most powerful countries in the world and represent their national interests. Such a performance by the most powerful countries does not lead to the creation and development of world peace, but on the contrary, to deepen differences and create fertile ground for conflict. Contrary to the idea that the multi-polar nature of international relations and more intense connection of communities will reduce the chance for major traditional armed conflicts in the world is dominated by the deepening instability. The modern world is increasingly presents itself as a space of global tumult and turmoil uproar, dominated time of insecurity is more than ever a doubt in peacetime growth prospects of the world. (Stojanovic, 2009) From the standpoint of security, progress is a kind of history of risk and contradictory process between freedom of human choice and objective limits of this choice given that the man is always risky before a final choice between the reality and the infinite possibilities, a safe present and an uncertain future. (Beck, 1992)

This state of security of society is interwoven with a large number of hazards and risks of them in all variations, it does not mean that the community in the Balkan is struggled and surrendered to the evil fate. On the contrary, properly introduced to risk, their presence and destructive capabilities, and reconcile themselves with the fact that they have to live in an environment where risks are immanent phenomena. The fact is that these hazards that exist permanently increase and build up the capacity of which can seriously harm social systems have serious consequences is essentially a problem of social security in the Balkan. It is one of the effects of globalization - the globalization of threats and risks.

Properly introduced above facts, science, by putting the need for progress and preserve peace in the foreground, examines the causes of hazards and take measures to reduce or neutralize their effects. It became clear that only a deeper danger, the circumstances under which they occur, causes and ways of manifesting his power, can effectively respond to the destructive operation.

Contemporary challenges pose a potential threat to the security of society in general, and can, in a negative connotation, gain the attributes of growing risk events and threats, as well as direct and obvious indicators of compromising the existing security situation. Challenges, risks and threats begin where stops confidence and 
security and include all phenomena of the modern world that can become a potential threat for the democratic process of the Western Balkan.

Contemporary social relations engendered the new security challenges, risks and threats, internal and external character caused primarily non-military events and phenomena with asymmetrical features. The internal challenges and threats have increased. And they are expressed through the presence of weapons of mass destruction, terrorist acts, acts of various nationalist and separatist movements, bad economics, and so on. Internal challenges have a negative operating direction of the attributes of destructive capacity. The risk of these events is increased by the fact that modern societies have no or poor protection mechanisms. The internal challenges and threats are not limited to the territory of a particular country, but exert negative effects on the environment, but also interact with external challenges and threats.

The external challenges and threats are also a wide array of events and phenomena with destructive capacity, for example: terrorism, energy dependence, migration, hunger, achieving a common feature, especially negative impact on the individual state and society. Together, the internal and external challenges and threats, cause political and economic disruption, with short-term or long-term consequences.

On this factual is known theorist Ulrich Beck, launched the phrase "Risk society", signaling the consequences of progress and technical and technological development that the sum of the dangers and risks of a range which is not easy to predict.

The theory of risk society has at least opened the box knowledge of the risk and the light of day performed its social dimension. It is obvious that the dangers and their consequences do not leave the same impression on all communities of the Western Balkan.

Said condition implies a serious issue, which is the way out of the 'age of uncertainty'- whether in the setting Enlightenment - rationalist understood progress or build a society that is based on a different paradigm, which postulates take into account the need for progress and more comfortable life but also the fact that there are limitations in whose framework progress must move. 


\section{Seccurity}

2.3The impact of social security on the development of democracy in the countries of the Western Balkan

After the wars that led to the breakup of SFR Yugoslavia, the question of security problems prevailing in the Western Balkan at the beginning of XXI century. On the internal level, the problem is the nature of each country. Western Balkan countries are still faced with many problems that prevent democratization. One of the primary problems is a lack of consensus on the basic principles, values and priorities of the political and economic systems, as well as the city of the future in Euro-Atlantic integration. Company are, and further, the core is divided, which is an obstacle to democratic consolidation, as well as normal operation of an institution. Religious and ethnic heterogeneity affect the economic development of these countries, especially those with complex religious structure, primarily Bosnia and Herzegovina, Macedonia, Serbia, Montenegro. Civil society is underdeveloped and almost complete monopoly of political parties in political organization and presentation. Media freedom is threatened, both by government and by powerful economic and political groups, which in this way are trying to complete the process of "hijacking" or subjugation of the country. (Hadzic, 2012)

Political, legal and economic institutions are not at the level of modern normality where weight. I do not perform well their basic function and one gets the impression that the public office and state assets which have exploited as a source of power and protection. This supports a number of international security issues such as organized crime and corruption, which, increasingly, are becoming a major obstacle to economic development when the probability of military conflict decreased. These anomalies threaten to nullify all the positive effects of "unfinished peace." Associations of crime and state structures operate regardless of borders, which is why this threat has a regional character. (Sretenovic, 2006) Western Balkan countries are both expensive, and inefficient and weak, or unable to provide the citizens is not the most important public good. One of the most important public good is the rule of law, which is chronically lacking in the Western Balkan. Parliaments are slow in making good laws, governments in their implementation, and the judiciary is still largely unreformed and a far cry from the projected independence from the other branches of government and powerful non-state actors. Different sectors are sources of securitization, or prevalent social, because questions of national identity are becoming the most common 
organizational factor of struggle and fear. (Kegljir and Vitkof, 2006) Resurface religion, which represents and sets a line of demarcation (Croat / Serb, three entities in Bosnia and Herzegovina, Kosovo Albanian / Kosovo Serb Orthodox Macedonians / Albanians), but it is not securitized as such, but the most important element in defining the national identity.

In the Western Balkans, political and ethnic ground has not stopped trembling, because, in contrast to other parts of Europe, believes that the processes are not completed construction of nation states run the disintegration of socialist Yugoslavia.

The international community and local actors securitize increasingly transnational nature of criminal phenomena, such as illegal drug trafficking, trafficking (prostitution - often in the form of slave-like and organized illegal migration to the West), weapons and, of course, organized crime in general. These challenges are supported and reinforced by said above conflicts, weak state structures and numerous fissures and conflicts within societies. (Yenigun, 2010)

When the state leadership and the citizens of the long-term face a crisis (as is the case in the Western Balkan), often prevalent belief that it is insoluble or that the proposed solution will bring significantly higher costs and losses than gains, which favors the development of political and other forms of extremism. Extremism, in turn, causes the appearance of the vicious circle of violence being committed through organized crime and terrorism. (Laszlo, 2007) Although violence is primarily an integral part of terrorism, it is also an aid organized crime, which provides financial, political, social and other support to terrorism. Terrorism, on the other hand, provides a wider space for the development of organized crime. In such an interdependent area, everything is possible and anyone can become a victim and a target. Accordingly, in analyzing the activities aimed at combating terrorism and organized crime, it is necessary to recognize their relationship but also causes of connectivity. Special attention deserves and gains upon fanaticized people willing to die for an idea, money or other of them a distinct value. It is important to note that a number of reasons, primarily because of the political and socio-economic situation, most of the Western Balkan countries would be fertile ground for terrorism in the post-socialist period. (Islami, 2007) 
According to Sheehan in his doctoral thesis, the factors supporting the preceding paragraph are as follows (Sheehan, 2000):

- The growth of extreme nationalism as a key factor in the conflict in the former Yugoslavia. Although the degree of nationalism in the region culminated in the early nineties of the last century, two decades after the conflict has not been yet completely sidelined from the political discourse. Hate speech is still spreading in some media, the absence of a sizeable step towards reconciliation and the accountability for crimes committed during the wars, with the exception of the Hague tribunal, contributes to the further existence of extreme nationalism in the Western Balkan.

- In the countries formed after the breakup of SFR Yugoslavia immediately arose authoritarian regimes, which were unable to establish full control over state functions, which caused extreme corruption and nepotism and therefore the decrease in the efficiency of state bodies. Weak states have not been able to establish civilian control over the security system or to redirect irregular activities in the economic and political decision-making, the legal and institutional flows. Unstable coalition governments and internal conflicts in many countries still further weaken the effectiveness of the government and the mechanisms of their control. Political elites are deeply divided, and ad hoc coalitions established out of necessity, are composed mainly of various partners whose relationship is based largely on mutual conditionality.

- The rule of law is still in most countries of the Western Balkan has not reached full swing, which is reflected in a significant rate of organized crime and corruption.

- The difficult economic and social situation is a major source of political instability, and thus the opportunities for the development of extremism and the use of violence (terrorism). Decades of descent of the national economy are large part of the population in the region plummeted into poverty, wherein employment is prospected in minimum. The absence of significant investments and low living standard of the population is a source of political instability and social discontent, which could easily spill over into support for radical political options. 


\section{Securiaty}

\section{CONCLUSION}

Changed security constellation of the world, the disappearance of the bipolar confront not yielded the expected results, i.e., increasing security and creating conditions for undisturbed progress. On the contrary, the idea of social justice, the single market and culture remained positive ideas with positive effects in rich countries, while poor countries expanded range of problems. The increased hiatus lost between the rich and the poor, population growth especially in poor countries, the weakened economies of many countries, dizzying technological development especially in the field of nuclear energy and information technology increases the number of hazards, lack of food and energy resources, an increase in the number of terrorist acts increased the number of natural and other disasters, and so on. These problems are not just a local issue, tied to the nation-state. All the above features are readily evident in the Western Balkan. Spatial and temporal dimensions of modern threats has become negligible, considering that any of these hazards, does not depend on the physical boundaries of a state, but equally threatens both rich and poor countries. Difference creates only the existence of capacity to protect or prevent negative effects. The consequences to people, property and the environment are such that they have long-term effects affecting a larger number of actors, creating fear and panic, disrupt the normal functioning of society.

Security of the state and society is uncertain. Modern universal aspirations to security, designed to globalization, show results, projected through domination and especially monopolistic exploitation of the world's natural resources by megacorporations. Mechanisms global dominance, powerful states, are realized through the imposition of dependent modernization and neo, by reducing the territorial sovereignties, cultural imperialism, causing internal conflicts and military force in order to achieve their own political interest. For countries that want to preserve their national identity, but also to exist in a fair international community, the current development of globalization is an extension of the range of challenges at national levels. Democratic processes in the countries of the Western Balkan are subject to these changes in terms of security. The development of social consciousness in all areas of social development of the countries of the Western Balkan, not accompanied by the need to react to changes on a global scale. This discrepancy leads to poor development of social security in each country, and in the region, too. 


\section{LITERATURE}

1. Adomeit, H.: Soviet Risk-taking and crisis Behavior: A theoretical and empirical analysis, Boston, 1982.

2. Almond, G.A., Flanagan,S., Mundt,R.: Crisis, Chioce Change:Historical studies of political development, Boston, 1973.

3. Beck, U. (1992) Risk Society-Towards a New Modernity, London, Sage Publications.

4. Blummer, J.G., Gurevitch, M.: The Crisis of Public Communication, London, Ruotledge, 1995.

5. Bovens, M, thart, P.: Understanding Policy Fiascoes, New Brunswick: Transaction publishes, 1996.

6. Byrne, B., Baden, S.: Gender Emergencies and Humanitarian Assistance (Brussels: European Commission), 1995.

7. Charles and P. 't Hart (Eds), Coping with Crises:The Management of Disasters, Riots and Terrorism.

8. Dragisic, Z.: Pojam i poreklo sistema nacionalne bezbednosti, Zbornik radova, Fakultet bezbednosti, Beograd, 2007.

9. Fiamengo, A.: Osnove opste sociologije, Narodne novine, Zagreb, 1974.

10. Flin, R.: Sitting in the hot Seat: Leaders and teams for critical incidents. Chichester: Wiley. 1996.

11. Hajsmans, J.: The Politics of Insecurity, Routledge, 2006.

12. Hart, Springfield, IL: Charles T. Thomas. p 10, 2008.

13. Islami, Kastriot, National Security at the context of regional risks and threats (Proceedings of the International Conference: "On the development of the national security strategy", Tirana 21 September 2007, organized by IDM \& DCAF), Publishing House, Toena, Tirana, 2007

14. Joseph S. Nye Jr., Understanding International Conflicts, Fourth edition, (Foreward by Stenley Hoffman), Longman.

15. Karovic, S., Komazec, N.: Krize i krizni menadzment, Novi glasnik, 04/2009.

16. Kesetovic, Z., Kekovic, Z.: Sistemi kriznog menadzmenta, Fakultet za bezbjednost i zaštitu, Banjaluka.

17. Kesetovic, Z.: Teorijski koncept krize, Hrestomatija Prevencija krize, Fakultet bezbednosti, Beograd, 


\section{Securiagues}

18. Kovac, M., Stojkovic, D.: Strategijsko planiranje odbrane, Vojnoizdavacki zavod, Beograd, 2009.

19. Kovacevic, S.: Osnovi bezbednosti, VSUP, 1996.

20. Larouuse enciklopedija, Treci tom, JPJ, Beograd, 1999.

21. Living with risk: A Global View of Disaster reduction Initiatives (Geneva: UN International strategy for Disaster reduction

22. M. T. Savic, A., Delic, M., Bajagic, M.: Bezbednost sveta, Policijska akademija, Beograd, 2002.

23. Michel T. Charles and Paul 't Hart. (1989) The World of Crises and Crises Management. In Coping with Crises: The Management of Disasters, Riots and Terrorism, edited by Uriel Rosenthal, M.T. Charles and Paul 't.

24. Miller, B., Nacionalna, socijalna i ljudska bezbednost, Ljudska bezbednost, Fakultet civilne odbrane, Beograd, 1/2003.

25. Opca enciklopedija, IX tom:Rac-szu, Jugoslovenski leksikografski zavod, Zagreb, 1981.

26. Recnik srpskohrvatskog kniizevnog jezika, knjiga treca i cetvrta, Matica Srpska, Novi Sad, 1971

27. Rijpma, J.A.: Complexity, tight-coupling and reliability Connecting normal accidents theory and high reliabillity Rosenthal, Uriel.

28. Rosenthal, U., M.T.Charles and P. 't Hart: "The world of crisis and crisis management" in: U. Rosenthal.

29. Samson, Simic, D.: Nauka o bezbednosti, Sluzbeni list SRJ, Fakultet politickih nauka, Beograd, 2002.

30. Sijan, Z. Uloga politika bezbednosti drzava zapadnog Balkana u utvrdjivanju spoljnopolitickih prioriteta posle 2000. godine, doktorska disertacija, Beograd Springfield: Charles C. Thomas, p.10, 1989, New York, 2003, p. 2.

31. Sretenovic, M.: Uticaj geopolitickih interesa velikih sila na bezbednost drzava Zapadnog Balkana, SNO, Beograd, 2006

32. Stojanovic, S.: Globalizacija i bezbednosne perspektive sveta, Vojnoizdavacki zavod, Beograd, 2009.

33. Hart, P., Rosenthal, U., Kouzmin, A.: Crisis decision making: The centralization thesis media. Alpen aan de Rijn. 